Radziewicz, Julian. „Takt i nietakt w wychowaniu”. Nowa Szkoła 5 (1996). Rowid, Henryk. Podstawy i zasady wychowania. Warszawa: 1957.

Dorota Grabowska*

\title{
Tomasz Piechniczek, Kultura i religijność w życiu miejskiej spoteczności lokalnej. Socjologiczne studium przypadku. Kłodnica w Rudzie Slaskiej, Katowice: Studio NOA Ireneusz Olsza, 2015, ss. 280.
}

DOI: http://dx.doi.org/10.12775/PCh.2015.022

Nakładem Wydawnictwa Studio NOA Ireneusz Olsza opublikowana została w 2015 roku praca Tomasza Piechniczka pod tytułem: Kultura i religijność w życiu miejskiej społeczności lokalnej. Socjologiczne studium przypadku. Kłodnica w Rudzie Ślaskiej. Jak podaje Autor we Wstępie, postanowił on ,„poddać analizie fenomen kłodnickiej religijności, traktując parafię jako grupę społeczną, badając jej funkcje i strukturę społeczną [...] oraz dostrzegając w religii i religijności istotny element lokalnej kultury, współkonstytuujący ład społeczny" (s. 10).

Recenzowana książka składa się z ośmiu rozdziałów. Trzy pierwsze zostały poświęcone omówieniu teoretycznych zagadnień pracy. Autor wyszedł od rozważań na temat sposobów rozumienia kultury (na gruncie socjologii), by następnie przejść do określenia roli kultury w kształtowaniu tożsamości zbiorowej (rozdział 1, s. 13-36). W rozdziale drugim (s. 37-78) - opartym na analizie bogatej literatury przedmiotu - zaprezentował wybrane ujęcia socjologiczne religii i religijności, omówił społeczno-integracyjne funkcje religijności, a także poruszył problem praktyk religijnych jako manifestacji przynależności do wspólnoty lokalnej. Dopełnieniem teoretycznej części opracowania uczynił rozważania dotyczące specyfiki tożsamości lokalnej Kłodnicy, poświęcając szczególną uwagę kościelności kłodnickiej jako formie kultury lokalnej (rozdział 3, s. 79-104).

W rozdziale czwartym przedstawione zostały założenia metodologiczne podjętych badań (s. 105-122). Autor rozpoczął od określenia przedmiotu

* Dr Dorota Grabowska - absolwentka pedagogiki i historii, pracownik nieetatowy w Wydziale Nauk Pedagogicznych Uniwersytetu Mikołaja Kopernika w Toruniu. Adres: Wydział Nauk Pedagogicznych UMK, Katedra Historii Wychowania, ul. Lwowska 1, 87-100 Toruń: e-mail: dogra@umk.pl. 
i celu badań. Następnie sformułował problemy badawcze, które przyjęły formę następujących pytań: czy istnieją kulturowe wzory religijności specyficzne dla Kłodnicy?; czy dokonuje się zmiana kulturowych wzorów religijności znamiennych dla Kłodnicy?; na czym polega zmiana kulturowego wzoru religijności specyficznego dla Kłodnicy? Postawione problemy stały się podstawą do skonstruowania hipotez. W dalszej kolejności Autor określił zmienne, krótko omówił zastosowane techniki badań oraz scharakteryzował środowisko respondentów.

Kolejne rozdziały książki poświęcono prezentacji zgromadzonego materiału empirycznego. Podjęte w nich analizy, niektóre bardzo szczegółowe, dotyczyły: form zaangażowania badanych w życie społeczności lokalnej (rozdział 5, s. 123-157), problemów socjalizacji i tożsamości religijnej (w obliczu dokonujących się przemian kulturowych) oraz kościelności jako manifestacji więzi z parafią (rozdział 6, s. 158-183), form i motywów uczestnictwa w życiu religijnym oraz znaczenia lokalnych wzorów religijności (rozdział 7, s. 184-215), kulturowego i religijnego wymiaru tożsamości lokalnej (rozdział 8, s. 216-242).

Jak podaje Autor w Zakończeniu (s. 243-249), rezultaty przeprowadzonych badań pozwoliły na dostrzeżenie stopniowego odchodzenia części respondentów od religijności tradycyjnej ku opierającemu się na zaangażowaniu, świadomemu zawierzeniu (wyborowi). Z drugiej strony - zwłaszcza wśród przedstawicieli młodego pokolenia - „odnotować należy spadek liczebności deklaracji i postaw, które można uznać za w pełni religijne, w rozumieniu kościelnej ortodoksji. Religia utraciła część swej mocy konstytuującej porządek moralny, pomimo wciąż dominującej pozycji - ujętej w kategorii oczywistości kulturowej - dla coraz większej liczby osób staje się jedną z wielu opcji światopoglądowych, [...] rzeczywistością, która poprzez doktrynalny rygoryzm [...] musi konkurować z osobistymi pasjami” (s. 247). T. Piechniczek wykazuje ponadto, że obrzędowość religijna coraz częściej sprowadzona jest do tak zwanej niereligijnej kościelności (ograniczona zostaje nierzadko do uczestnictwa w uroczystościach Bożego Narodzenia, Objawienia Pańskiego, Wielkanocy czy Bożego Ciała oraz rytuałów przejścia, w szczególności chrztów, ślubów i pogrzebów). Wskazuje on również na zjawisko dystansowania się części badanych od różnorakich powinności, jakie związane są z przynależnością do wspólnoty parafialnej. Jak stwierdza na koniec: „Maleje znaczenie parafii w procesie budowania tożsamości lokalnej. Dla wielu Kłodnica jest «tylko» domem, sypialnią, punktem odniesienia trajektorii codzienności, której centra znajdują się gdzie indziej - w miejscu nauki, pracy, zakupów, rozrywki, usług czy realizacji pasji. Własna prze- 
strzeń, ograniczona płotem posesji lub ścianami segmentu, w każdej chwili może zostać porzucona na rzecz innej, lepszej (np. ze względu na pracę), zatem nie warto zabiegać o relacje nawet najbliższego sąsiedztwa, nie mówiąc o potrzebie budowania wspólnoty lokalnej" (s. 248-249).

Praca Tomasza Piechniczka to interesujące, napisane w zrozumiały sposób studium na temat kultury i religijności miejskiej społeczności lokalnej Kłodnicy. Z pewnością można uznać ją za ważny przyczynek do dalszych badań nad podjętą problematyką. Lekturę książki w znacznym stopniu ułatwiają tabele z danymi liczbowymi, aneks, na który składa się wykorzystany w badaniu kwestionariusz wywiadu, a także wykaz literatury i stron internetowych.

Tomasz Różański*

* Dr Tomasz Różański jest adiunktem w Katedrze Socjologii Edukacji i Pedagogiki Społecznej Wydziału Nauk Pedagogicznych UMK w Toruniu. Adres: Wydział Nauk Pedagogicznych UMK, ul. Lwowska 1, 87-100 Toruń; e-mail: tomrozan1@umk.pl. 